\title{
Pengaruh Persepsi Kemudahaan Penggunaan, Efektivitas, Risiko Terhadap Minat Dan Penggunaan Financial Technologi (Fintech) Dengan Minat Sebagai Variabel Mediasi
}

\author{
Andi Setiawan ${ }^{1}$ \\ andisetiawan.as931@gmail.com \\ Siti Rofingatun ${ }^{1}$ \\ Kurniawan Patma ${ }^{1}$ \\ Jurusan Akuntansi, Fakultas Ekonomi dan Bisnis Universitas Cenderawasih
}

\begin{abstract}
This study aims to provide empirical evidence of the influence of perception of ease of use, effectiveness of risk to interest, and use of Financial Technology (Fintech) with interest as a variable of mediation in Jayapura city.

The study used primary data obtained by distributing questionnaires online. The data analysis method used is by Structure Equation Model (SEM) approach with WarpPLS 7.0. The sampling method used is purposive sampling technique. Purposive sampling is a sampling technique of data sources with certain considerations or criteria.

The results of this study were seen from the P/sig values $(0.230>0.005)$. Thus the ease of use has a positive and insignificant effect on the use of financial technology (fintech) with an interest as mediation. Judging from its P/sig values $(0.015<0.005)$ thus the effectiveness has a positive and significant effect on the use of financial technology (fintech) with interest as mediation. Judging from its P/sig values $(0.330>0.005)$ thus the risk has a positive and insignificant effect on the use of financial technology (fintech) with interest as mediation.
\end{abstract}

Keywords: financial technology; Interest; Perception Ease of use; Effectiveness; Risk

\begin{abstract}
Abstrak
Penelitian ini bertujuan untuk memberikan bukti empiris pengaruh persepsi kemudahan penggunaan, efektivitas risiko terhadap kepentingan, dan penggunaan Teknologi Finansial (Fintech) dengan kepentingan sebagai variabel mediasi di kota Jayapura.

Penelitian menggunakan data primer yang diperoleh dengan menyebarkan kuesioner secara online. Metode analisis data yang digunakan adalah dengan pendekatan Structure Equation Model (SEM) dengan WarpPLS 7.0. Metode pengambilan sampel yang digunakan adalah teknik purposive sampling. Purposive sampling merupakan teknik pengambilan sampel sumber data dengan pertimbangan atau kriteria tertentu.

Hasil penelitian ini dilihat dari nilai P / sig $(0,230>0,005)$. Dengan demikian kemudahan penggunaan berpengaruh positif dan tidak signifikan terhadap penggunaan financial technology (fintech) dengan kepentingan sebagai mediasi. Dilihat dari nilai P / signya $(0,015<0,005)$ maka efektifitas berpengaruh positif dan signifikan terhadap penggunaan financial technology (fintech) dengan kepentingan sebagai mediasi. Dilihat dari nilai $\mathrm{P} /$ signya $(0,330>0,005)$ maka risiko berpengaruh positif dan tidak signifikan terhadap penggunaan financial technology (fintech) dengan mediasi bunga.
\end{abstract}

Kata kunci: financial technology, Bunga, Persepsi Kemudahan Penggunaan, Efektivitas, Risiko

\section{Pendahuluan}

Financial technology (fintech) adalah penggunaan teknologi dalam sistem keuangan yang menghasilkan produk layanan, teknologi, dan/atau model bisnis baru serta berdampak pada stabilitas moneter, stabilitas sistem keuangan, dan/atau efisienssi, kelancaran, keamanan, dan keandalan sistem pembayaran (Indonesia, 2017). Dari waktu ke waktu layanan keuangan selalu mengalami evolusi seperti di era sekarang, meskipun layanan keuangan sejak dahulu sudah mendapatkan sentuhan teknologi seperti Anjungan Tunai Mandiri (ATM), kartu debet dan lain sebagainya, tetapi di era sekarang lebih banyak berbagai fitur layanan keuangan yang berbasis teknologi digital yang mulai 
bermunculan sehingga diharapkan dapat menjawab kebutuhan masyarakat.

Berdasarkan hasil survey yang di laksanakan oleh Asossiasi Penyelenggara Jasa Internet Indonesia (APJII) tahun 2018 bahwa pengguna internet di Indonesia mencapai 171,17 Juta jiwa atau sebesar 64,8\% dari total penduduk Indonesia 264,16 juta dengan kata lain persentase pertumbuhan pengguna internet dari tahun 2017 mengalami kenaikan sebesar 10,12\% (Perilaku \& Indonesia, 2018). Total pengguna internet di kalangan Mahasiswa telah mencapai $92.1 \%$ sampai tahun lalu.

Proses akuntansi sekarang memakai teknologi memiliki dampak yang sangat signifikan dimana percepatan dalam pemilihan investasi, pembayaran dan pencatatatan menjadi lebih cepat dan akurat sesuai dengan pedoman akuntasi. Fintech \& Implementasinya, (2018) Aktivitas-aktivitas Fintech keuangan dapat diklasifikasikan ke dalam 5 (lima) kategori yaitu; 1. Pembayaran, transfer, kliring dan penyelesaian (Payment, Clearing and Settlement); 2. Deposito, pinjaman dan penambahan modal (Deposits,Lending and Capital Raising); 3. Manajemen Risiko (Risk Management); 4. Dukungan Pasar (Market Support); 5. Manajemen Investasi (Invesment Management).

Hal ini belum direspon oleh seluruh masyarakat dengan mulai beradaptasi dengan perkembangan yang terjadi dengan teknologi digital atau dengan katalain masih menggunakan cara tradisional dalam bertransaksi. Menurut hasil survey yang di lakukan APJII dari jumlah 171,17 juta pengguna internet $56 \%$ belum pernah bertransaksi menggunakan e-commerce alasan dari tidak pernah bertransaksi adalah tidak tau cara menggunakan aplikasi, khawatir barang tidak sampai dan merasa rumit kalau harus transfer (Annur, 2019).

Berdasarkan permasalahan diatas maka akan dilakukan penelitian dengan judul "Pengaruh Persepsi Kemudahan Penggunaan, Efektivitas , Risiko terhadap Minat dan Penggunaan Fintech" dengan minat sebagai variabel mediasi. Dengan variabel independen (X) adalah Persepsi Kemudahan Penggunaan (X1), Efektivitas (X2) dan Risiko (X3), variabel mediasi (Z) Minat sedangkan variabel Dependen (Y) adalah Penggunaan Fintech. Dengan objek penelitian adalah lingkungan Universitas Cenderawasih. Sedangkan penelitian sebelumnya dilakukan di Mahasiswa Fakultas Ekonomi dan Bisnis Islam, Universitas Islam Negeri Walisongo Semarang.

\section{Rumusan Masalah} berikut:

1. Apakah persepsi kemudahan penggunaan berpengaruh terhadap minat dalam menggunakan financial technology (fintech)?

2. Apakah persepsi kemudahan penggunaan berpengaruh terhadap penggunaan financial technology (fintech) ?

3. Apakah Persepsi Kemudahan Penggunaan berpengaruh terhadap penggunaan financial technology (fintech) dengan minat sebagai mediasi ?

4. Apakah efektivitas berpengaruh terhadap minat dalam menggunakan financial technology (fintech) ?

5. Apakah efektivitas berpengaruh terhadap penggunaan financial technology (fintech) ?

6. Apakah efektivitas berpengaruh terhadap penggunaan financial technology (fintech) dengan minat sebagai mediasi ?

7. Apakah persepsi risiko berpengaruh terhadap minat dalam menggunakan financial technology (fintech)?

8. Apakah persepsi risiko berpengaruh terhadap penggunaan financial technology (fintech) ?

9. Apakah persepsi risiko berpengaruh terhadap penggunaan financial technology (fintech) dengan minat sebagai mediasi?

10. Apakah Minat dapat berpengaruh terhadap Penggunaan Financial Technology (Fintech) ?

11. Apakah persepsi kemudahan penggunaan, efektivitas dan risiko dapat berpengaruh terhadap peggunaan financial technology (fintech) secara bersama-sama?

12. Apakah ada perbedaan minat antara mahasiswa, dosen dan investor dalam penggunaan financial technology (fintech)? 


\section{Tujuan Penelitian}

1. Untuk Menganalisis dan memberikan bukti empiris pengaruh Persepsi Kemudahan Penggunaan terhadap minat dalam menggunakan financial technology (fintech).

2. Untuk Menganalisis dan memberikan bukti empiris pengaruh persepsi kemudahan penggunaan berpengaruh terhadap penggunaan financial technology (fintech).

3. Untuk Menganalisis dan memberikan bukti empiris pengaruh Persepsi Kemudahan Penggunaan berpengaruh terhadap penggunaan financial technology (fintech) dengan minat sebagai mediasi.

4. Untuk Menganalisis dan memberikan bukti empiris pengaruh efektivitas terhadap minat dalam menggunakan financial technology (fintech).

5. Untuk Menganalisis dan memberikan bukti empiris pengaruh efektivitas berpengaruh terhadap penggunaan financial technology (fintech).

6. Untuk Menganalisis dan memberikan bukti empiris pengaruh efektivitas berpengaruh terhadap penggunaan financial technology (fintech) dengan minat sebagai mediasi.

7. Untuk Menganalisis dan memberikan bukti empiris pengaruh Persepsi Risiko Berpengaruh terhadap minat dalam menggunakan financial technology (fintech).

8. Untuk Menganalisis dan memberikan bukti empiris pengaruh persepsi risiko berpengaruh terhadap penggunaan financial technology (fintech).

9. Untuk Menganalisis dan memberikan bukti empiris pengaruh persepsi risiko berpengaruh terhadap penggunaan financial technology (fintech) dengan minat sebagai mediasi.

10. Untuk Menganalisis dan memberikan bukti empiris Minat dapat berpengaruh terhadap penggunaan financial technology (fintech).

11. Untuk Menganalisis dan memberikan bukti empiris pengaruh Persepsi kemudahan penggunaan, Efektivitas dan Risiko terhadap peggunaan financial technologi (fintech) secara bersama-sama.

12. Untuk menganalisis dan memberikan bukti empiris perbedaan minat antara mahasiswa, dosen dan investor dalam Penggunaan financial technology (Fintech).

\section{Tinjauan Pustaka}

\subsection{Theory Technology Acceptence Model (TAM)}

Model yang diperkenalkan oleh Davis (1989) ini merupakan model yang paling banyak dipergunakan dalam penelitian sistem informasi, karena menghasilkan validitas yang baik. TAM merupakan adaptasi dari teori yang dikembangkan oleh Fisbein dan Ajzen (1975), yaitu Theory of Reasoned Action (TRA) yang merupakan teori tindakan yang berdasarkan dengan satu asumsi bahwa reaksi dan persepsi seseorang terhadap suatu hal akan menentukan sikap dan perilaku orang tersebut.

TAM menambahkan dua konstruk utama ke dalam model TRA, kedua konstruk utama itu adalah kegunaan persepsian (perceived usefulness) dan kemudahan penggunaan persepsian (perceived ease of use) (Davis et al, 1989:320). Kegunaan persepsian (perceived usefulness) dan kemudahan penggunaan persepsian (perceived ease of use) keduanya mempunyai pengaruh ke niat perilaku (behavioral intention). kemudahan penggunaan persepsian (perceived ease uf use) mempengaruhi kegunaan persepsian (perceived usefulness).

\subsection{Theory Of Planned Behavior (TPB)}

Teori kedua yang dapat menjelaskan penerimaan individu dalam menggunakan teknologi adalah Theory of Planned Behavior (TPB), yang di ungkapkan oleh (Ajzen, 1991) teori ini menjelaskan tentang kepercayaan dan risiko dapat mempengaruhi individu berminat atau mempunyai keinginan untuk menggunakan teknologi. Teori yang di ungkapkan oleh Ajzen pada tahun 1991 ini telah banyak digunakan untuk menjelaskan tentang perilaku dalam pemakaian atau penggunaan teknologi. TPB memiliki kelebihan yaitu mampu menganalisis situasi dimana individu ketika tidak dapat mengontrol perilakunya. 


\subsection{Definisi Fintech}

Menurut Douglas W. Arner \& Janos Barberis, (2015) Menyatakan Financial Technology atau yang sering di sebut (Fintech) adalah penggunaan teknologi untuk memberikan solusi keuangan. sedangkan menurut surat edaran yang di terbitkan oleh Bank Indonesia No.18/22/DKSP tentang Penyelenggaraan Layanan Keuangan Digital (LKD) menjelelaskan bahwa kegiatan layanan keuangan digital adalah penggunaan teknologi berbasis mobile atauppun berbasis web dalam kegiatan layanan sistem pembayaran dan keuangan yang dilakukan dengan kerja sama dengan pihak ketiga dalam rangka keuangan inklusif (Indonesia, 2016).

\subsection{Persepsi Kemudahan Penggunaan (Perceived Ease Of Use)}

Davis F. D. 1989 Dalam Fathul Wahid, (2007) Menyatakan persepsi tentang kemudahan sebuah teknologi didefinisikan sebagai suatu ukuran dimana seseorang percaya bahwa komputer dapat dengan mudah dipahami dan digunakan. intensitas penggunaan dan interaksi antara pengguna dengan sistem juga dapat menunjukan kemudahan pengunaan. sistem lebih sering digunakan menunjukan bahwa sistem tersebut lebih dikenal, lebih mudah di operasikan dan lebih mudah digunakan oleh penggunannya (Adams et al., 1992).

\subsection{Efektivitas}

Pengertian efektivitas menurut KBBI, (2014) berasal dari kata "Efektif" yang berarti efek, akibat, pengaruh atau dapat membawa hasil. dalam hal ini efektivitas yang di maksud penulis adalah hasil yang di dapat dari penggunaan suatu teknologi yang sesuai dengan tujuan pengguna. (Davis, 2014) menyatakan Persepsi Kegunaan adalah suatu ukuran kepercayaan seseorang bahwa dengan menggunakan suatu teknologi akan meningkatkan prestasi kerja mereka.

Dalam beberapa kasus, Perceives of usefulness juga di artikan sebagai keuntungan dalam dunia teknologi kemanfaatan berarti kemungkinan seseorang yang menggunakan suatu teknologi akan memperoleh suatu hasil yang diinginkan (Liebana-Cabanillas et. al., 2014).

\subsection{Risiko}

Menurut Al-Smadi, (2012) Risiko dianggap sebagai persepsi pelanggan terhadap adanya ketidakpastian dan juga konsekuensi negatif untuk membeli produk atau memakai jasa. sebelum menggunakan suatu teknologi seseorang tentu akan mempertimbangkan Risiko dari penggunaan tersebut. Muhhammad Fadhli, (2016) mengemukakan Risiko merupakan sesuatu yang menghadirkan penilaian individu terhadap kemungkinan yang berhubungan atas hasil positif maupun negatif dari suatu transaksi atas situasi.

\subsection{Minat (Behavioral Intention to Use)}

Kusumah 2009 Dalam Rahayu, (2019) Mendefinisikan bahwa minat merupakan salah satu aspek psikis manusia yang dapat mendorong untuk mencapai tujuan. seseorang akan berminat menggunakannya apabila individu tersebut menilai sesuatu yang bermanfaat bagi dirinya dan mendatangkan kepuasan. Minat merupakan kecenderungan perilaku untuk tetap menggunakan suatu teknologi (Wibowo, 2008).

\subsection{Penggunaan Fintech (Actual To Use)}

Indikator dari variabel penggunaan Fintech dalam penelitian ini adalah pengguna baru menggunakan atau yang sudah menggunakan fintech. penggunaan dalam hal konteks penggunaan teknologi, dapat dikatakan dengan penggunaan sesungguhnya (Actual Use) yang merupakan bentuk pengukuran terhadap frekuensi dan durasi waktu penggunaan teknologi. Dengan kata lain pengukuran penggunaan sesungguhnya (Actual Use) diukur sebagai jumlah waktu yang digunakan untuk berinteraksi dengan suatu teknologi dan besarnya frekuensi penggunaannya. 


\subsection{Model Penelitian} berikut:

Berdasarkan pengembangan hipotesis diatas, maka dapat disusun model penelitian sebagai

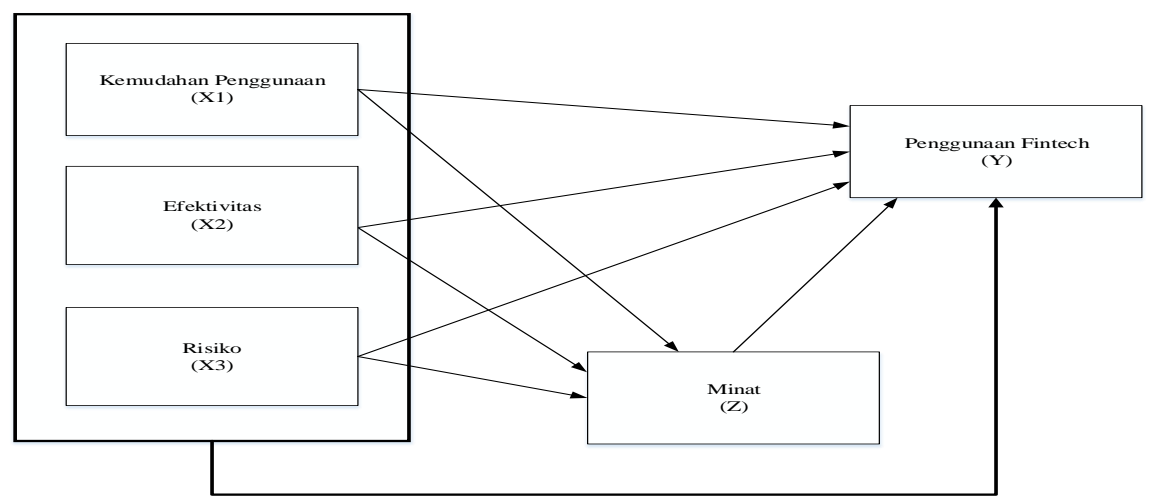

Gambar 1. Model Penelitian (Sumber: Penulis, 2020)

\subsection{Hipotesis}

H1: Persepsi Kemudahan penggunaan berpengaruh terhadap minat menggunakan Financial Technology (fintech).

H2: Persepsi Kemudahan Penggunaan berpengaruh positif terhadap Penggunaan Financial Technology (Fintech).

H3:Persepsi Kemudahan Penggunaan berpengaruh terhadap penggunaan financial technology (fintech) melalui Minat sebagai Mediasi

H4: Persepsi Efektivitas berpengaruh terhadap Minat menggunakan Financial Technology (Fintech).

H5: Persepsi Efektivitas berpengaruh terhadap Penggunaan financial technology (fintech).

H6: Persepsi Efektivitas berpengaruh terhadap Penggunaan Financial Technology (Fintech) dengan Minat sebagi Mediasi.

H7: Risiko berpengaruh terhadap minat menggunakan Financial Technology (fintech).

H8: Risiko berpengaruh terhadap Penggunaan Financial Technology (Fintech)

H9: Risiko berpengaruh terhadap Penggunaan Financial Technology (Fintech) dengan Minat sebagai Mediasi.

H10: Minat berpengaruh terhadap Penggunaan Fintech

H11: Persepsi kemudahan penggunaan, efektivitas dan risiko berpengaruh terhadap Penggunaan Fintech secara bersama-sama.

\section{Metode Penelitian}

3.1 Jenis Penelitian

Penelitian ini adalah penelitian kausalitas yang mencoba untuk menentukan alasan atau penyebab untuk kondisi yang ada.

\subsection{Lokasi Penelitian}

Lokasi yang diambil oleh penulis dalam penelitian ini adalah Galeri Investasi Universitas Cenderawasih (GI UNCEN).

\subsection{Populasi dan Sampel}

Populasi yang digunakan dalam penelitian ini adalah seluruh Dosen, Mahasiswa dan Investor di Galeri Investasi Universitas Cenderawasih (GI UNCEN).

Penelitian ini peneliti menggunakan metode penyampelan dengan Purposive sampling. Purposive sampling adalah teknik pengambilan sampel sumber data dengan pertimbangan atau kriteria tertentu. Alasan menggunakan teknik purposive sampling adalah karena tidak semua sampel memiliki 
kriteria yang sesuai dengan fenomena yang diteliti. Penelitian ini berkaitan dengan penggunaan fintech sehingga yang menjadi responden harus memenuhi kriteria tertentu. Responden yang mudah diperoleh adalah di GI UNCEN dan responden yang ada di dalam GI UNCEN ada tiga yaitu, Dosen, Mahasiswa dan Investor, dengan kriteria-kriteria sebagai berikut:

1. Dosen

Adapun kriteria yang dijadikan sebagai sampel penelitian yaitu:

a) Memakai teknologi (Smartphone)

b) Terdapat aplikasi financial technology (fintech) di (smartphone) seperti OVO, DANA, LinkAja, GoPay, M-banking

c) Menggunakan aplikasi financial technology (fintech) seperti OVO, DANA, LinkAja, GoPay, M-banking

d) Melakukan transaksi $\geq 2$ kali dalam 1 bulan.

2. Mahasiswa

Adapun kriteria yang dijadikan sebagai sampel penelitian yaitu:

a) Memakai teknologi (Smartphone)

b) Terdapat aplikasi financial technology (fintech) di (smartphone) seperti OVO, DANA, LinkAja, GoPay, M-banking

c) Menggunakan aplikasi financial technology (fintech) seperti OVO, DANA, LinkAja, GoPay, M-banking

d) Melakukan transaksi $\geq 1$ kali dalam 1 bulan.

3. Investor

Adapun kriteria yang dijadikan sebagai sampel penelitian yaitu:

a) Investor individu

b) Investor yang terdaftar di Phintraco Sekuritas

c) Investor melakukan trading saham

d) Investor adalah mahasiswa di lingkungan Universitas Cenderawasih (GI Uncen)

e) Melakukan isi ulang RDI melalui M-banking

f) Aktif bertransaksi dalam 1 tahun terakhir

\subsection{Jenis dan Sumber Data}

Data yang digunakan dalam penelitian ini adalah data primer yang diperoleh melalui jawaban responden melalui kuesioner. Data primer merupakan data yang diperoleh secara langsung dari sumbernya. Data primer dalam penelitian ini adalah data mengenai tanggapan responden terhadap variabel persepsi kemudahan penggunaan, efektivitas, risiko terhadap minat dan penggunakan fintech. Kuesioner diberikan dan di isi oleh cluster yang sudah di tentukan yaitu dosen, mahasiswa dan investor.

\subsection{Metode Pengumpulan Data}

Metode pengumpulan data yang digunakan dalam penelitian ini adalah dengan menyebarkan kuesioner online kepada responden. Responden akan menjawab butir-butir pernyataan dengan

\section{Hasil Dan Pembahasan}

\section{Uji Validitas}

Setelah dilakukannya penghapusan indikator K2, E4, M2, M4 dan P2 maka nilai AVE dari kostruk Kemudahan, Efektivitas, Minat dan Penggunaan fintech yang semula tidak memenuhi syarat validitas konvergen, setelah dilakukan pengolahan data ulang dengan mengeluarkan lima (5) indikator telah mengalami peningkatan yang semula $\mathrm{K}$ dari 0,419 menjadi 0,520 , E dari 0,453 menjadi 0,546, $\mathrm{M}$ dari 0,433 menjadi $0,635, \mathrm{P}$ dari 0,452 menjadi 0,555 sehingga semua variabel sudah memiliki nilai AVE >0,5. Dengan demikian nilai AVE dapat disimpulkan bahwa konstruk tersebut telah valid. Kemudian jika dilihat dari nilai loading factor ada beberapa indikator yang memiliki nilai loading 
factor dibawah 0,7 namun masih di atas 0,5 maka nilai tersebut masih dinyatakan valid.

Nilai loading ke konstruk lainnya menunjukan korelasi konstruk dengan setiap indikator lebih besar dari pada ukuran konstruk lainnya. Jadi dapat disimpulkan bahwa validitas diskriminan telah terpenuhi.

\section{Uji Reliabilitas}

Uji Reliabilitas dapat dilihat dari nilai Cronbach's Alpha dan Composite Reliability dan membandingkan dengan Rule of Tumb yang sudah dijabarkan bahwa Cronbach's Alpha dan Composite Reliability harus memiliki di atas 0,7 sehingga konstruk dapat memenuhi uji reliabilitas. Konstruk ada yang tidak memenuhi syarat pada Cronbach's Alpha namun untuk Composite Reliability setiap konstruk telah memenuhi syarat parameter konstruk yaitu di atas 0,7. Cronbach's Alpha mengukur batas bawah nilai reliabilitas suatu kostruk, sedangkan composite reliability mengukur nilai sesungguhnnya reliabilitas suatu konstruk (Chin, 1995). Namun, composite reliability dinilai lebih baik dalam mengestimasi konsistensi internal suatu konstruk (Salisbury, Chin, Gopal, \& Newsted, 2002).

Rule of Tumb nilai alpha atau composite reliability harus lebih besar dari 0,7 meskipun nilai 0,6 masih dapat diterima (Hair et al., 2008). Namun sesungguhnya uji konsistensi internal tidak mutlak untuk dilakukan jika validitas konstruk telah terpenuhi, karena konstruk yang valid adalah konstruk yang reliabel, sebaliknya konstruk yang reliabel belum tentu valid (Cooper et al., 2006).

\section{Evaluasi Model Struktural (Inner Model)}

Langkah selanjutnya adalah dengan mengevaluasi model struktural (Inner Model), tahap ini dilakukan dengan melihat nilai adj $R$-squared untuk setiap variabel laten endogen sebagai kekuatan prediksi dari model struktural kemudian tahap selanjutnya yaitu test untuk menguji $Q^{2}$ predictive relevance dan Goodness of Fit (GOF).

Selanjutnya dilakukan uji inner model dengan melihat nilai adj $R$-squared, dimana nilai adj $R$ squared pada variabel Penggunaan Financial technology (Fintech), menunjukan nilai 0,414 yang berarti bahwa variabel kemudahan penggunaan, efektivitas, risiko, dan minat sebesar $41,4 \%$ dan sisanya $58.6 \%$ dijelaskan oleh variabel lain yang tidak ada dalam penelitian ini atau faktor lain yang tidak ada pada model.

Selain dengan melihat nilai $R$-squared, suatu model dikatakan memiliki nilai predictive relevance jika nilai $Q$-squared $>0$, nilai $Q^{2}$ predictive relevance penggunaan financial technology (fintech) menunjukan nilai 0,424 >0 yang berarti model memiliki nilai predictive relevance. Model telah memenuhi ke sepuluh kriteria model fit and quality indices, sehingga dapat disimpulkan bahwa model tersebut telah memenuhi syarat model fit.

\section{Uji hipotesis}

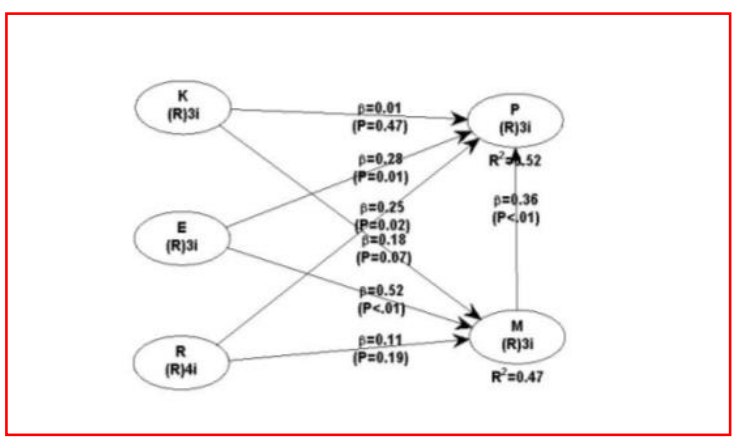

Gambar 2. Hasil Output Warp PLS (Sumber: Penulis, 2020) 


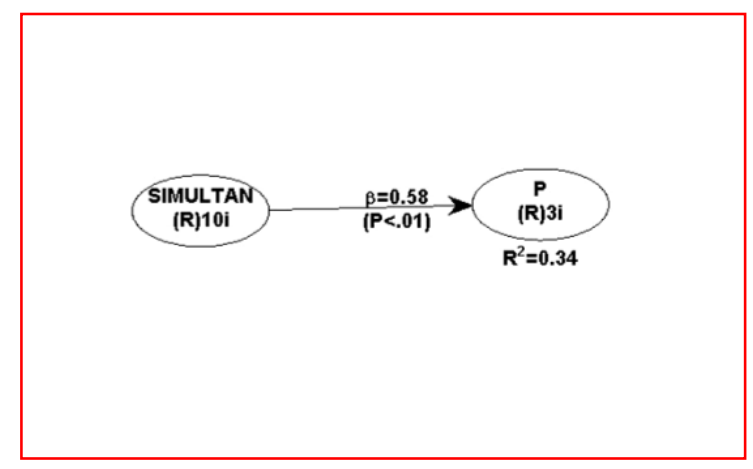

Gambar 3. Pengujian secara Simultan (Sumber: Penulis, 2020)

Tabel 4. Hasil Output Path Coefficient Model Direct And Indirect Effect

\begin{tabular}{lccc}
\hline Variabel Penelitian (Hipotesis) & Path Coefficient & P value & Ket \\
\hline K -> M & 0,181 & 0,070 & Ditolak \\
K -> P & 0,011 & 0,467 & Ditolak \\
E -> M & 0,524 & $<0,001$ & Diterima \\
E -> P & 0,279 & 0,010 & Diterima \\
R -> M & 0,109 & 0,192 & Ditolak \\
R -> P & 0,247 & 0,021 & Diterima \\
M -> P & 0,365 & 0,001 & Diterima \\
K -> M -> P & 0,066 & 0,230 & Ditolak \\
E -> M -> P & 0,191 & 0,015 & Diterima \\
R -> M -> P & 0,040 & 0,330 & Ditolak \\
KER -> P & 0,582 & $<0,001$ & Diterima \\
\hline
\end{tabular}

Sumber: Penulis (2020)

Uji Hipotesis 1(H1) : Persepsi Kemudahan Penggunaan terhadap Minat Menggunakan Financial Technology (Fintech)

Berdasarkan pengujian menunjukan bahwa H1: ditolak sehingga dapat disimpulkan bahwa kemudahan penggunaan tidak berpengaruh terhadap minat menggunakan fintech. Penelitian ini tidak sejalan dengan penelitian yang dilakukan oleh Muhamad wildan yang menyatakan bahwa persepsi kemudahan penggunaan berpengaruh terhadap penggunnaan fintech.

Pada penelitian ini, kenaikan dari penggunaan fintech yang dipengaruhi oleh kemudahan penggunaan fintech tersebut tidak berpengaruh. Hal tersebut dikarenakan tidak semua orang menggunakan fintech, dikarenakan kebutuhan setiap orang yang berbeda -beda sehingga jika seseorang memang membutuhkan layanan dari fintech dia akan menggunakan aplikasi tersebut walaupun sulit.

\section{Uji hipotesis 2 (H2) Persepsi Kemudahan Penggunaan terhadap Penggunaan Financial Technology (Fintech)}

Berdasarkan pengujian menunjukan bahwa H2: ditolak sehingga dapat disimpulkan bahwa kemudahan penggunaan tidak berpengaruh terhadap penggunaan fintech. Penelitian ini sejalan dengan penelitian yang dilakukan oleh (Irmadhani, 2012) hal ini berarti semakin tinggi persepsi kemudahan penggunaan maka semakin tinggi pula penggunaan fintech namun hasil kenaikan dari penggunaan fintech yang dipengaruhi oleh persepsi kemudahan penggunaan tersebut tidak signifikan. 
Uji hipotesis 3 (H3) Persepsi Kemudahan Penggunaan terhadap Penggunaan Financial Technology (Fintech) Dengan Minat Sebagai Variabel Mediasi

Berdasarkan pengujian menunjukan bahwa $\mathbf{H 3}$ ditolak sehingga dapat disimpulkan bahwa kemudahan penggunaan tidak berpengaruh terhadap penggunaan fintech dengan minat sebagai mediasi. Minat dalam penelitian ini memperlemah persepsi kemudahan penggunaan terhadap penggunaan fintech hal ini dikarenakan seseorang berminat untuk menggunakan fintech bukan di karenakan mudahnya, melainkan belum adanya kebutuhan untuk menggunakan layanan fintech sehingga pengguna belum berminat.

\section{Uji hipotesis 4 (H4) Efektivitas terhadap Minat Menggunakan Financial Technology (Fintech)}

Berdasarkan hasil pengujian menunjukan bahwa $\mathbf{H 4}$ diterima sehingga dapat disimpulkan bahwa efektivitas berpengaruh terhadap minat menggunkan financial technology (fintech). Hal ini sejalan dengan penelitian yang dilakukan oleh (Wildan, 2019) yang menyatakan bahwa efektivitas memiliki pengaruh terhadap minat menggunakan fintech. Seseorang berminat dalam menggunanan fintech di karenakan dapat bertransaksi dimana saja dan kapan saja selama ada koneksi internet yang stabil.

\section{Uji hipotesis 5 (H5) Efektivitas terhadap Penggunaan Financial Technology (Fintech)}

Berdasarkan hasil pengujian bahwa $\mathbf{H 5}$ diterima sehingga dapat disimpulkan bahwa efektivitas berpengaruh terhadap penggunaan financial technology (fintech). penelitian ini sejalan dengan hasil penelitian yang dilakukan oleh (I Gusti Mayun Prabawalingga, 2016) yang menyatakan bahwa terdapat pengaruh antara persepsi efektivitas terhadap penggunaan financial technology (fintech). Kepercayaan seseorang terhadap sebuah fintech dapat meningkatkan pekerjaannya maka akan semakin besar terjadinya perilaku penggunaan fintech tersebut. Efektivitas penggunaan fintech dapat diketahui dari kepercayaan seorang pengguna fintech dalam memutuskan penerimaan fintech apakah memberikan kontribusi positif bagi dirinya.

\section{Uji hipotesis 6 (H6) Efektivitas terhadap Penggunaan Financial Technology (Fintech) Dengan Minat Sebagai Mediasi}

Berdasarkan hasil pengujian bahwa H6 diterima sehingga dapat disimpulkan bahwa efektivitas berpengaruh terhadap penggunaan financial technology (fintech) dengan minat sebagai mediasi. Hasil ini sejalan dengan penelitian yang dilakukan oleh (I Gusti Mayun Prabawalingga, 2016) dan Al-maghrabi et al. (2011) dimana hasil analisis untuk model ini menunjukan bahwa konstruk persepsi efektivitas berpengaruh positif terhadap minat penggunaan layanan $e$-commerce.

Berdasarkan hasil penelitian yang dilakukan peneliti dan berdasarkan penelitian yang dilakukan peneliti-peneliti sebelumnya, dapat disimpulkan bahwa variabel minat memperkuat hubungan antara persepsi efektivitas dalam penggunaan fintech yang mana variabel ini merupakan suatu faktor yang dominan untuk menjelaskan manfaat dari penggunaan suatu sistem.

\section{Uji hipotesis 7 (H7) Risiko terhadap Minat Menggunakan Financial Technology (Fintech)}

Berdasarkan hasil pengujian bahwa $\mathbf{H 7}$ ditolak sehingga dapat disimpulkan bahwa risiko tidak berpengaruh terhadap minat menggunakan financial technology (fintech). Penelitian ini sejalan dengan penelitian yang di lakukan oleh (Arif Reza Maharama, 2018) yang menyatakan bahwa risiko tidak berpengaruh terhadap minat. Berdasarkan penelitian yang dilakukan oleh peneliti penyebab risiko tidak berpengaruh terhadap minat penggunaan fintech adalah sebagian orang masih cenderung konservatif dalam menggunakan layanan keuangan sehingga lebih baik bertransaksi dengan cara yang konvensional atau bertatap muka secara langsung.

\section{Uji hipotesis 8 (H8) Risiko terhadap Penggunaan Financial Technology (Fintech)}

Berdasarkan hasil pengujian bahwa $\mathbf{H 8}$ diterima sehingga dapat disimpulkan bahwa risiko berpengaruh terhadap Penggunaan financial technology (fintech). Penelitian ini sejalan dengan penelitia yang di lakukan oleh (Azizi, 2016) menyatakan bahwa risiko berpengaruh terhadap penggunaan e-banking. Berdasarkan penelitian yang dilakukan oleh peneliti pengujian ini membuktikan bahwa risiko yang semakin kecil berpengaruh terhadap keputusan seseorang untuk menggunakan fintech. Artinya apabila risiko yang semakin kecil, maka semakin banyak individu 
untuk menggunakan fintech. Sebaliknya, apabila risiko semakin besar maka keputusan seseorang untuk menggunakan fintech akan cenderung mengalami penurunan.

\section{Uji hipotesis 9 (H9) Risiko terhadap Penggunaan Financial Technology (Fintech) Dengan Minat Sebagai Mediasi}

Berdasarkan hasil pengujian bahwa $\mathbf{H 9}$ ditolak sehingga dapat disimpulkan bahwa risiko tidak berpengaruh terhadap penggunaan financial technology (fintech) dengan minat sebagai mediasi. Berdasarkan penelitian yang dilakukan oleh peneliti minat memperlemah risiko terhadap penggunaan fintech hal tersebut dikarenakan sebagian orang masih baru akan mengarah ke penggunaan fintech sehingga masih khawatir dengan adanya faktor risiko yang besar dengan menggunakan layanan fintech maka dari itu sebagian orang masih menggunakan layanan konvensional dan mulai mempelajari mengenai fintech ini.

\section{Uji hipotesis 10 (H10) Minat terhadap Penggunaan Financial Technology (Fintech)}

Berdasarkan hasil pengujian bahwa H10 diterima sehingga dapat disimpulkan bahwa minat berpengaruh terhadap penggunaan financial technology (fintech). Hasil yang diperoleh peneliti dalam penelitian ini menjelaskan bahwa perilaku individu untuk menggunakan fintech dipengaruhi dari munculnya minat awal terhadap fintech tersebut. Minat awal yang positif akan dapat mendorong perilaku seseorang yang semakin besar untuk menggunakan fintech, namun apabila minat awal yang terbentuk adalah negatif maka akan dapat mengurangi perilaku seseorang untuk menggunakan fintech. Dengan kata lain, pengguna fintech akan bertransaksi menggunakan fintech apabila telah timbul minat untuk menggunakan fintech.

\section{Uji hipotesis 11 (H11) Persepsi Kemudahan Penggunaan, Efektivitas dan Risiko terhadap Penggunaan Financial Technology (Fintech)}

Berdasarkan hasil pengujian bahwa H11 diterima sehingga dapat disimpulkan bahwa persepsi kemudahan penggunaan, efektivitas dan risiko berpengaruh terhadap penggunaan financial technology (fintech) setelah di uji secara bersama-sama. Hal ini menunjukan bahwa semakin tinggi persepsi kemudahan, efektivitas dan risiko yang semakin kecil maka akan meningkatkan keputusan seseorang menggunakan layanan fintech. Berdasarkan hasil dri nilai adjusted $R$ square $\left(\mathrm{R}^{2}\right)$ yang diperolah 0,414 (41.4\%). Hal ini berarti persepsi kemudahan penggunaan, efektivitas dan risiko berpengaruh positif dan mempengaruhi $41.4 \%$ perubahan pada penggunaan fintech, sedangkan sisanya $58.6 \%$ dijelaskan variasinya oleh variabel lain.

\section{Uji Beda Variabel Minat}

Berikut tabel dibawah ini adalah hasil pengujian uji beda analysis of variance yang dapat dilihat pada bagian signifikansi. Variabel yang digunakan dalam pengujian adalah Minat.

Tabel 5. Uji beda minat

\begin{tabular}{lrrccc}
\hline \multicolumn{1}{c}{ Minat } & $\begin{array}{c}\text { Sum of } \\
\text { Squares }\end{array}$ & df & $\begin{array}{c}\text { Mean } \\
\text { Square }\end{array}$ & F & Sig. \\
\hline $\begin{array}{l}\text { Between } \\
\text { Groups }\end{array}$ & 35.590 & 2 & 17.795 & 8.965 & .000 \\
Within & 113.143 & 57 & 1.985 & & \\
Groups & & & & & \\
Total & 148.733 & 59 & & & \\
\hline
\end{tabular}

Selanjutnya hasil yang du uji melalui uji post hoc LSD diketahui perbedaan antar kelompok yang dirangkum sebagai berikut:

a Dosen dan investor memiliki nilai sig >0,005 sehingga dapat disimpulkan tidak terdapat perbedaan yang sangat signifikan pada minat penggunaan financial technology (fintech), dengan 
kata lain penggunaan aplikasi fintech antara dosen dan investor tidak menghasilkan minat yang berbeda. Kerena investor lebih dominan memakai mobile banking dibandingkan fintech sebab dalam melakukan topup ke Rekening dana nasabah (RDN) saat ini baru bisa menggunakan layanan tersebut, kemudian untuk dosen pun demikian berdasarkan hasil pengujian menunjukan bahwa dosen lebih dominan dalam penggunaan layanan mobile banking sehingga tidak terdapat perbedaan yang sangat signifikan.

$b$ Investor dan mahasiswa memiliki nilai sig $<0,005$ sehingga dapat disimpulkan terdapat perbedaan yang sangat signifikan pada minat penggunaan financial technology (fintech), dengan kata lain penggunaan aplikasi fintech antara investor dan mahasiswa menghasilkan minat yang berbeda. Hal tersebut dapat dilihat dari dominan penggunaan investor lebih untuk top up RDN sedangkan mahasiswa lebih kepenggunaan Go-Pay, sehingga terdapat perbedaan yang sangat signifikan.

c Dosen dan mahasiswa memiliki nilai sig <0,005 sehingga dapat disimpulkan terdapat perbedaan yang sangat signifikan pada minat penggunaan financial technology (fintech), dengan kata lain penggunaan aplikasi fintech antara dosen dan mahasiswa menghasilkan minat yang berbeda. Hal tersebut dapat dilihat dari penggunaan aplikasi fintech yang dominan di gunakan dosen adalah mobile banking sedangkan mahasiswa Go-Pay.

\section{Penutup}

\subsection{Kesimpulan}

Berdasarkan rumusan masalah, tujuan penelitian, landasan teori, hipotesis dan hasil penelitian, dapat disimpulkan bahwa:

1. Persepsi kemudahan penggunaan tidak berpengaruh terhadap minat menggunakan financial technology (fintech).

2. Persepsi kemudahan penggunaan tidak berpengaruh terhadap penggunaan financial technology (fintech).

3. Persepsi kemudahan penggunaan tidak berpengaruh terhadap penggunaan financial technology (fintech) dengan minat sebagai variabel mediasi..

4. Efektivitas berpengaruh terhadap minat menggunakan financial technology (fintech)

5. Efektivitas berpengaruh terhadap penggunaan financial technology (fintech)

6. Persepsi efektivitas berpengaruh terhadap penggunaan financial technology (fintech) dengan minat sebagai variabel mediasi.

7. Risiko tidak berpengaruh terhadap minat menggunakan financial technology (fintech)

8. Risiko berpengaruh terhadap penggunaan financial technology (fintech).

9. Risiko tidak berpengaruh terhadap penggunaan financial technology

10. (fintech) dengan minat sebagai variabel mediasi.

11. Minat berpengaruh terhadap penggunaan financial technology (fintech)

12. Persepsi kemudahan penggunaan, efektivitas dan risiko berpengaruh terhadap penggunaan financial technology (fintech) secara bersama-sama.

13. Perbedaan minat perkelompok dijelaskan dibawah ini :

a) Dosen dan investor memiliki nilai sig $>0,005$ sehingga dapat disimpulkan tidak terdapat perbedaan yang sangat signifikan pada minat penggunaan financial technology (fintech), dengan kata lain penggunaan aplikasi fintech antara dosen dan investor tidak menghasilkan minat yang berbeda.

b) Investor dan mahasiswa memiliki nilai sig $<0,005$ sehingga dapat disimpulkan terdapat perbedaan yang sangat signifikan pada minat penggunaan financial technology (fintech), dengan kata lain penggunaan aplikasi fintech antara investor dan mahasiswa menghasilkan minat yang berbeda.

c) Dosen dan mahasiswa memiliki nilai sig <0,005 sehingga dapat disimpulkan terdapat perbedaan yang sangat signifikan pada minat penggunaan financial technology (fintech), dengan kata lain penggunaan aplikasi fintech antara dosen dan mahasiswa menghasilkan minat yang berbeda. 


\subsection{Keterbatasan Penelitian}

Beberapa keterbatasan dalam melakukan penelitian ini, yang dapat dijadikan sebagai pertimbangan antara lain:

a. Data pada penelitian ini diambil hanya berdasarkan survey yang di isi oleh responden sehingga data yang dihasilkan mempunyai kesempatan terjadinya bias. Kemungkinan terjadi bias sebagai akibat dari adanya perbedaan persepsi antara peneliti dengan reponden terhadap pernyataan yang di ajukan.

b. Penetapan sampel dalam penelitian ini belum menghitung probability populasi di GI Uncen sehingga dalam hasil penelitian ini bisa jadi lemah.

\subsection{Saran}

\section{Bagi peneliti/akademis}

a. Bagi peneliti selanjutnya agar mengembangkan penelitian ini dengan menambah jumlah populasi dan sampel dan juga memperluas ruang lingkup.

b. Diharapkan untuk peneliti selanjutnya dapat melakukan revisi kembali terhadap butir pernyataan pada penelitian ini agar dapat meningkatkan kualitas yang diperoleh.

c. Penelitian selanjutnya disarankan menggunakan variabel lain seperti Kepercayaan, kesesuaian, keamanan, privasi dan fitur layanan.

d. Penelitian selanjutnya disarankan untuk korelasi dalam mediasi bisa ditambahkan variabel Intensitas.

e. Peneliti selanjutnya harus memperhatikan kriteria penyampelandan kriteria penentuan sampel.

\section{Bagi Pihak Galeri Investasi Universitas Cenderawasih}

a. Kedepannya pencatatan data untuk jumlah total investor yang terdafatar lebih di perhatikan agar memudahkan bagi peneliti selanjutnya.

\section{Daftar Pustaka}

Adams, D. A., Nelson, R. R., Todd, P. A., Adams, B. D. A., Nelson, R. R., \& Todd, P. A. (1992). "Perceived Usefulness, Ease of Use , and Usage of Information Technology: A Replication." 16(2), 227-247.

Ajzen, I. (1991). "The Theory of Planned Behavior." Organization Behavior and Human Decision Processes, 179-211.

Al-Smadi, M. dan S. A. A.-W. (2012). “Dampak E-Banking pada Kinerja Bank Yordania _ Buka Jurnal Akses."

Alvani Amaerita Harefa. (2018). "Financial Technology, Regulasi dan Adaptasi Perbankan Di Indonesia." Management Journal, 9220(1), 1-11.

Amalia, F., Chishti, S., \& Barberis, J. (2016). "The Fintech Book: The Financial Technology Handbook For Investors, Entrepreneurs And Visionaries," 31(3), 345.

Andryani, Y. D., Program, M., Ilmu, S., Negara, A., Administrasi, D., Ilmu, F., .. Airlangga, U. (2014). "Inklusivitas Program Laku Pandai (Layanan Keuangan Tanpa Kantor Dalam Rangka Keuangan Inklusif)," 2.

Annur, C. M. (2019). "56\% Pengguna Internet Indonesia Belum Pernah Bertransaksi E-Commerce."

Ardhiani, L. N. (2015). “Analisis Faktor-faktor Penerimaan Penggunaan Quipperschool.com Dengan Menggunakan Pendekatan Teori (TAM \& TPB) Di SMA Negeri \& Yogyakarta."

Arjunwadkar, P. Y. (2018). "Fintech: The Technology Driving Disruption in the Financial Services Industry."

Arif Reza Maharama, N. K. (2018). Pengaruh Kepercayaan, Kemudahan dan Persepi Risiko Terhadap Keputusan Pembelian Jasa GoJek Di Kota Semarang Yang Dimediasi Minat Beli Sebagai Variabel Intervening. 203-213.

Azizi, M. (2016). Pengaruh persepsi kemudahan, Kepercayaan Dan Risiko Terhadap Keputusan Nasabah Menggunakan E-Banking Pada PT Bank BNI Syariah KC Yogyakarta. 
Chang Boon Patrick Lee, G. W. (2010). "Including Subjective Norm and Technology Trust in the Technology Acceptance Model : A Case of E-Ticketing in China," 41(4), 40-51.

CNBC Indonesia. (2019). Startup Unicorn ke-5, Namanya OVO. Retrieved from https://www.cnbcindonesia.com

Dampararas \& Luhdini Nilamtiti. (2017). Persepsi Kemudahan Penggunaan, Persepsi Efektivitas, Kepercayaan dan Risiko terhadap Penggunaan Internet Banking.

Davis, F. D. (2014). "Perceived Usefulness, Perceived Ease of Use, and User Acceptance of Information Technology." 13(3), 319-340.

Dendy Agustiyan. (2019). "Sosialisasi OJK Tentang Equity Crowdfunding." Retrieved from https://www.finansialku.com/peraturan-equity-crowdfunding/

Douglas W. Arner, Janos Barberis, R. P. B. (2015). "The Evolution of Fintech: A New Post-Crisis Paradigm?" 0-45.

Fathul Wahid. (2007). "Teknologi Informasi dan Pendidikan, Ardana Media dan Rumah produksi Informatika, UII, Yogyakarta." 52-53.

Fintech, T. K., \& Implementasinya, K. D. (2018). "Teknologi Keuangan (Fintech) : Konsep dan Implementasinya di Indonesia." March, 6.

Fransiska Ardela, S. . (2017). "Sudah Resmi! Pahami Klasifikasi Fintech Menurut Bank Indonesia." Retrieved from https://www.finansialku.com/klasifikasi-fintech-menurut-bank-indonesia/

Harlan, D. (2014). "Pengaruh Kemudahan Penggunaan, Kepercayaan dan Risiko Persepsian Terhadap Minat Bertransaksi Menggunakan E-Banking UMKM di Kota Yogyakarta.”

Hatta, N. (2018). Pengaruh Komunikasi Pemasaran Terhadap keputusan Pembelian dengan Minat Beli Sebagai Variabel Intervening Pada Konsumen KFC Citraland Makassar.

Hiroshi Fujii, Taeko Okano, Stuart Madnick, M. S. (2002). "MIT Sloan School of Management EAggregation: The Present and Future of Online Financial Service In Asia-Pacific," (July).

I Gusti Mayun Prabawalingga, I. K. Y. (2016). Persepsi Kemanfaatan dan Persepsi Kemudahan Dengan Minat Sebagai Variabel Intervening Terhadap Perilaku Penggunaan Sistem. 10, 33593390 .

Indonesia, B. (2016). "Penyelenggaraan Layanan Keuangan Digital.” 18, 6.

Indonesia, B. (2017). "Teknologi Finansial - Bank Sentral Republik Indonesia."

Irmadhani, M. A. N. (2012). "Pengaruh Persepsi Kebermanfaatan, Persepsi Kemudahan Penggunaan dan Computer Self Efficacy, Terhadap Penggunaan Online Banking.” 7.

Iswi Hariyani \& Cita Yustisia Serfiyani. (2015). "Perlindungan Hukum Donation Based Crowdfunding Pada Pendanaan Industri Kreatif Di Indonesia," 4.

Karim, M. A. (2018). "Pengaruh Penerimaan Sistem Pembayaran G0-Pay Menggunakan TAM (Technology Accetance Model) Terhadap Intensitas Penggunaan Layanan Gojek," 11.

KBBI. (2014a). "Arti kata efektif - Kamus Besar Bahasa Indonesia (KBBI) Online.” Retrieved from https://kbbi.web.id/efektif

KBBI. (2014b). “Arti kata mudah - Kamus Besar Bahasa Indonesia (KBBI) Online.” Retrieved from

KBBI. (2014). "Arti kata efektif - Kamus Besar Bahasa Indonesia (KBBI) Online."

Kusumasari, B., Wicaksono, K. W., Sidik, F., Achyani, F. T., Gana, F., Kiwang, A. S., \& Pandie, D. B. W. (2015). "Analisis Kebijakan dan Efektivitas Organisasi," 73.

Made, A., \& Ferdiana, K. (2019). Understanding Fintech Through Go - Pay, 4(2), 257-260.

Madian, A. (2018). "Cara Kerja Peer to Peer Lending Akseleran ." Retrieved from https://www.akseleran.co.id/blog/cara-kerja-peer-peer-lending-akseleran

Mahisa Bima Sakti, Endang Siti Astuti, K. (2010). Pengaruh Persepsi Pengguna Teknologi Informasi, Kemudahan Penggunaan, Risiko, Fitur Layanan Terhadap minat dan Penggunaan Anjungan Tunai Mandiri (ATM).

March Hot Asi Sitanggang. (2018). "Memahami mekanisme crowdfunding dan motivasi berpartisipasi dalam platform Kitabisa.com," 2.

Meiliyah Ariani, Z. (2017). "Pengaruh Kualitas Layanan, Keamanan, dan Risiko Terhadap Minat Menggunakan Line Pay," 457-467.

Muhhammad Fadhli, R. F. (2016). "Pengaruh Persepsi Nasabah Atas Risiko, Kepercayaan, Manfaat, Dan Kemudahan Penggunaan Terhadap Penggunaan Internet Banking.” 1(2), 264-276. 
Mulyana, Y. F. (2016). “Pengaruh Kepercayaan, Persepsi Risjiko dan Keamanan Terhadap Minat Beli Konsumen Pada Toko Online,” 26.

Muzdalifa, I., Rahma, I. A., \& Novalia, B. G. (2018). "Peran Fintech Dalam Meningkatkan Keuangan Inklusif Pada UMKM di Indonesia," 3(1).

Njatrijani, R. (2019). "Perkembangan Regulasi dan Pengawasan Financial Technology di Indonesia," (Februari), 462-474.

Otoritas Jasa Keuangan. (2019). "Perusahaan Fintech Lending Berizin dan Terdaftar di OJK." Retrieved from www.ojk.go.id

Perilaku, P., \& Indonesia, P. I. (2018). "Penetrasi \& profil perilaku pengguna internet indonesia." Maret.

Pikkarainen, K. (2004). Consumer acceptance of online banking: an extension of the technology acceptance model, 14(3), 224-235. https://doi.org/10.1108/10662240410542652

Rahayu, P. P. (2019). "Pengaruh Persepsi Kegunaan, Persepsi Kemudahan, Persepsi Kepercayaan dan Persepsi Kenyamanan Terhadap Minat Penggunaan Mobile Banking. ” 21.

Report, F. L. (2018). "Fintech Landscape Report May 2018 Indonesia," (May).

Roy Franedya, Tito Bosnia, C. I. (2018). Ini Dia Empat Jenis Fintech di Indonesia. Retrieved from https://www.cnbcindonesia.com/tech/20180110145800-37-1126/ini-dia-empat-jenis-fintech-diindonesia

Salle, H. T. (2018). “Analisis Faktor Determinan Terjadinya Kecenderungan Kecurangan (Studi Pada Pemerintahan Provinsi Papua)."

Sihombing, R. J. (2016). "Keabsahan electronic money di indonesia," 2.

Singapore, F. (2018). "Fintech Indonesia Report 2018 - The State of Play for Fintech Indonesia Fintech Singapore." Retrieved from https://fintechnews.sg/20712/indonesia/fintech-indonesiareport-2018/

Sironi, P. (2016). "FinTech Innovation_From Robo-Advisors to Goal Based Investing and Gamification - Paolo Sironi - Google Buku.” Retrieved from https://books.google.co.id/books?

Sofie Blakstad, R. A. (2018). FinTech Revolution_ Universal Inclusion in the New Financial Ecosystem - Sofie Blakstad, Robert Allen". Retrieved from https://books.google.co.id

Stacia Edina Hasiana Sitohang, S.Mn, C. (2017). "Apa Itu Robo Advisor dan Bagaimana Cara Kerjanya." Retrieved from https://www.finansialku.com/apa-itu-robo-advisor-dan-bagaimanacara-kerjanya/

Virgina Maulita Putri. (2019). Seputar Crowdfunding, Layanan yang Buat Ananda Badudu Ditangkap. Retrieved from https://inet.detik.com/cyberlife/d-4724603/seputar-crowdfunding-layanan-yangbuat-ananda-badudu-ditangkap

Wibowo, A. (2008). "Kajian Tentang Perilaku Pengguna Sistem Informasi Dengan Pendekatan Technology Acceptance Model."

Wildan, M. (2019). "Pengaruh Persepsi Kemudahan Penggunaan, Efektivitas, dan Risiko Terhadap Minat Bertransaksi Menggunakan Fintech.” 20.

Zimmermann, J. (2017). "Crowdfunding Berbasis Hadiah." Retrieved from https://www.nerdwallet.com/blog/small-business/reward-crowdfunding/ 